\title{
Identifying mechanical ventilation issues in classrooms
}

\author{
Julia Janiga ${ }^{1}$, Joanna Krzempka ${ }^{1}$, and Aleksandra Szczerbińska ${ }^{1, *}$ \\ ${ }^{1}$ Wroclaw University of Science and Technology, Department of Environmental Engineering, \\ Wyb. Wyspianskiego 27, 50-370 Wroclaw, Poland
}

\begin{abstract}
This article focuses on the issues of indoor air quality in mechanically ventilated classrooms. The aim of the study was to determine the reasons for inadequate air quality reported by occupants. Two different ventilation systems were assessed by measuring $\mathrm{CO}_{2}$ and VOC concentrations in classrooms during operating time. Results showed that in both cases, $\mathrm{CO}_{2}$ levels in the air, even though mostly acceptable, were exceeded throughout the measuring periods on occasion. Based on obtained data, in both cases probable causes for reported ventilation system malfunctions were proposed.
\end{abstract}

\section{Introduction}

Mechanical ventilation is designed to guarantee comfort for the building users. It is possible thanks to maintenance a proper air circulation, high air quality and appropriate conditions of microclimate. Therefore, we need the consistency with regulations of building code and requirements of Polish standards, which refer to ventilation [1].

In European Union, more and more countries pay attention to the necessity of introduction of the norms and monitoring program and the control of indoor air quality in educational establishments. In 2008 in Germany direction referring to air hygiene in schools were compiled. On the other hand, in France within the confines of ambient programmes some obligatory requirements were created for systematic monitoring and the indoor air quality (IAQ) control, as well as system of labelling of building materials [2].

The deployment of mechanical ventilation is not a guarantee of appropriate air parameters. Inappropriate operation as well as faulty design may be a cause of that. Poor air quality caused by a faulty ventilation system may be a reason for many health problems such as: problems with concentration, poor general sensation, chronic headaches, irritated mucosa, permanent tiredness, and even problems with nervous system [4, 5]. Above symptoms according to WHO may indicate that there occurs sick building syndrome. A building can be called sick when $20 \%$ of its users reckon that the cause of their poor general sensation symptoms is this building. It means that illness symptoms occur and strengthen only during their sojourning inside the building and disappear instantly after leaving [6].

\footnotetext{
*Corresponding author : aleszczerbinska@gmail.com
} 
Table 1. IAQ-related regulations in selected entities (in reference to a $10 \times 5 \times 3 \mathrm{~m}$ classroom occupied by 25 people). [3]

\begin{tabular}{|c|c|c|c|}
\hline Entity & $\begin{array}{c}\text { Outdoor air inflow, } \\
\mathrm{m}^{3} / \mathrm{h}\end{array}$ & $\begin{array}{c}\text { Maximum } \mathrm{CO}_{2} \\
\text { concentration, } \mathrm{ppm}\end{array}$ & $\begin{array}{c}\text { Air exchange factor, } \\
\mathrm{h}^{-1}\end{array}$ \\
\hline Portugal & 600 & 1250 & 4,0 \\
\hline Great Britain & 450 & 1500 & 3,0 \\
\hline Germany & 500 & 1500 & 3,3 \\
\hline Finland & 540 & 1200 & 3,6 \\
\hline France & $375-450$ & - & $2,5-3,0$ \\
\hline USA & 558 & 1080 & 3,7 \\
\hline Europe & 756 & 880 & 5,0 \\
\hline
\end{tabular}

Schools in Poland are ventilated gravitationally or mechanically. Due to the energy consumption pressure, buildings are quilted [7]. The consequence of that fact is that sealing and closing the way for infiltrative air, and limitations of room ventilating when outdoor temperatures are low. This is the reason for faulty gravitational ventilation. In case of mechanical ventilation, the majority of the ventilation systems in classrooms is controlled to maintain the comfort of the users, excluding the concentration of $\mathrm{CO}_{2}$. When using mechanical ventilation in many analysed classrooms an appropriate indoor air quality is kept, whereas in naturally ventilated buildings significant transgressions of permissible concentration of that substance is noticed [8].

Most commonly used indoor air quality indicator is $\mathrm{CO}_{2}$. The increase of its concentration is connected with deteriorating air quality because, as a product of breathing, it occurs naturally in ample quantities in a room. The borderlines between the concentrations: "low", "permissible" and "high" are contractual, whereas approximate values are assumed as per [1]:

Table 2. Suggested benchmark values of $\mathrm{CO}_{2}$ concentration.

\begin{tabular}{|l|l|}
\hline Comfortable & $\leq 1000 \mathrm{ppm}$ \\
\hline Acceptable & $1000-2000 \mathrm{ppm}$ \\
\hline Unacceptable & $\geq 2000 \mathrm{ppm}$ \\
\hline
\end{tabular}

Volatile organic compounds (VOC, VOCs) are chemical substances used to product cosmetics, civil chemistry, paints, solvents and elements of home equipment. Their presence in air is a cause of headaches, dysfunctions of endocrine system and increase the risk of tumour occurrence. They are also responsible for unpleasant aromatic effects frequently. When ventilation is faulty, the risk of dangerous levels of harmful concentration is high.

In this article, the research conducted in the educational establishments in Lower Silesia will be presented. The aim is to find the reasons for such a poor indoor air quality in classrooms, which are mechanically ventilated.

\section{Study objects and used equipment}

\subsection{Classroom 1}

The preschool is located in a 7-storey multi-use building and operates 5 days a week from 7 am to $5 \mathrm{pm}$. The measurements were taken in a classroom (floor area of circa $100 \mathrm{~m}^{2}$, dedicated for 25 children) located on the first floor. Adjacent to the classrooms are: staff and pupils' bathrooms, supply air unit room and a garbage chute. 
In the preschool a mechanical ventilation system is adopted. In the classroom in question air is supplied through a unit fitted with both a heater and a cooler, and exhausted through a separate, independently controlled system. According to the design schematics of the system, the supply air flow is equal to $395 \mathrm{~m}^{3} / \mathrm{h}$, and the exhaust air flow is equal to $380 \mathrm{~m}^{3} / \mathrm{h}$.

The study was conducted to determine the source of an intermittent, unpleasant odor in the classroom and to introduce counteract measures. The experiments were made from 7 am to $5 \mathrm{pm}$ on working day during the use of the classroom and during breaks. Carbon dioxide concentration measurements lasted during one month. In the article, two typical days will be shown. Second measurement was VOC concentration, only taken once. The actual supply and exhaust air flow was measured two times (before and after changed fan's power inverter). Equipment used in the study (in both cases) and its parameters are presented in Table 3.

Table 3. Parameters of the measuring instruments.

\begin{tabular}{|c|c|c|c|}
\hline $\begin{array}{c}\text { Type of the } \\
\text { instrument }\end{array}$ & $\begin{array}{c}\text { PID Tiger Phocheck } \\
\text { (photoionization } \\
\text { sensor) }\end{array}$ & $\begin{array}{c}\text { Testo 435-2 with a } \\
\text { vane anemometer }\end{array}$ & $\begin{array}{c}\text { Delta OHM } \\
\text { HD37AB17D (NDIR } \\
\text { sensor) }\end{array}$ \\
\hline Measured parameter & VOC concentration & Air velocity & $\mathrm{CO}_{2}$ concentration \\
\hline Measurement range & $1 \mathrm{ppb}-10,000 \mathrm{ppm}$ & $0-60 \mathrm{~m} / \mathrm{s}$ & $0-5000 \mathrm{ppm}$ \\
\hline Accuracy & $\begin{array}{c} \pm 5 \% \text { displayed } \\
\text { reading }\end{array}$ & $\begin{array}{c} \pm 0,1 \mathrm{~m} / \mathrm{s}+1,5 \% \\
\text { displayed reading }\end{array}$ & $\begin{array}{c} \pm 50 \mathrm{ppm}+3 \% \\
\text { displayed reading }\end{array}$ \\
\hline
\end{tabular}

\subsection{Classroom 2}

The second classroom is located in a large, 2-storey school building, operating on workdays from 6.30 am to $5 \mathrm{pm}$. The classroom is approx.. $65 \mathrm{~m}^{2}$ and houses 31 people ( 30 students and a tutor). There are 2 exterior walls in the room, one of which faces south and is fitted with windows making up circa $70 \%$ of its area.

In the school a mechanical air exhaust system is employed, while outdoor air is supplied through manually adjustable window valves (allowing for air flow of approx.. $600 \mathrm{~m}^{3} / \mathrm{h}$ in the discussed classroom). An individual roof fan with smooth rotation control is installed for each classroom. The classroom itself is fitted with a manual control switch and both temperature and carbon dioxide level sensors. The latter, located in a wall recess approx.. $40 \mathrm{~cm}$ above the floor, is designed to control the rotation of the fan. To prevent the students from accessing the sensor, the recess is screened with a net and shuttered.

The aim of the study was to assess the effectiveness of the ventilation system in the classroom- it was reported that the quality of air in the room was inadequate and its users described it as being stuffy. To carry out measurements the Delta OHM device was used during three days, at the time when preschool was opened.

\section{Results and discussion}

\subsection{Classroom 1}

Parallel to recording measurements, the room and its surroundings were inspected and the design was reviewed. The preschool's employees were asked to describe their habits and impressions with regard to the functioning of the ventilation system. Based on the information, three hypotheses were put forward:

- The air flow through the room is insufficient, causing odors to accumulate, 
- The supply air is contaminated with VOCs, Due to the negative pressure in the room, VOC-contaminated air infiltrates from adjacent rooms.

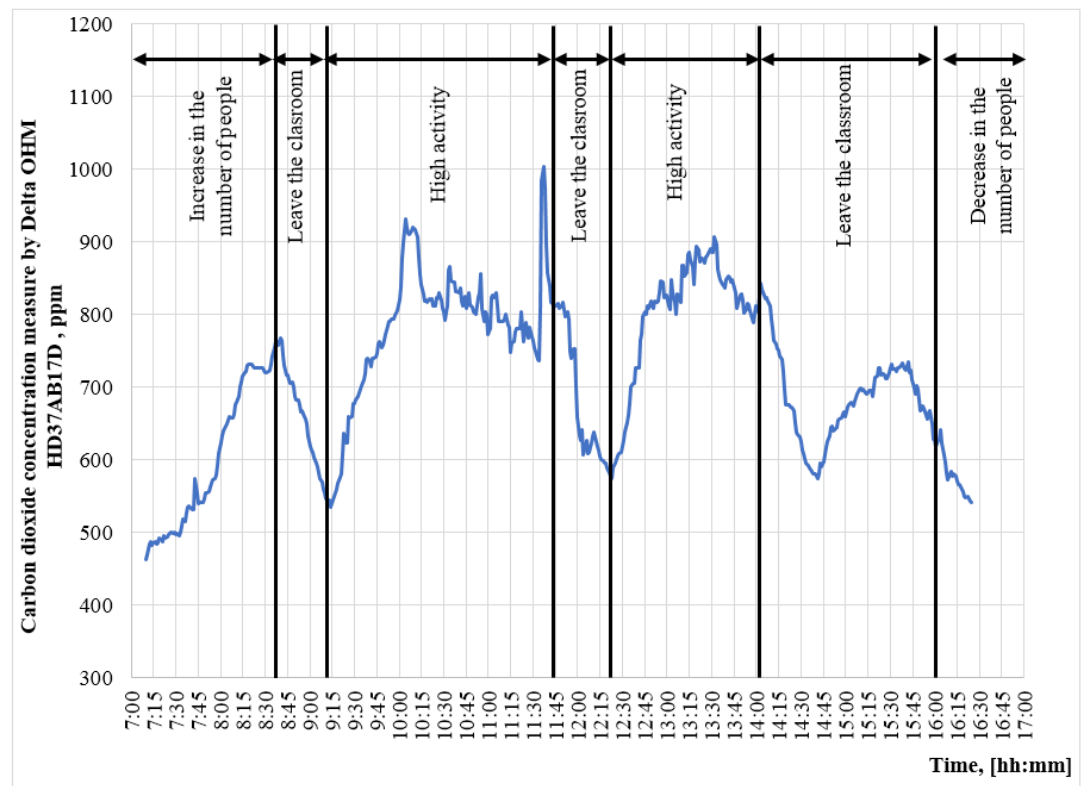

Fig. 1. Carbon dioxide concentration measurements- Day 1.

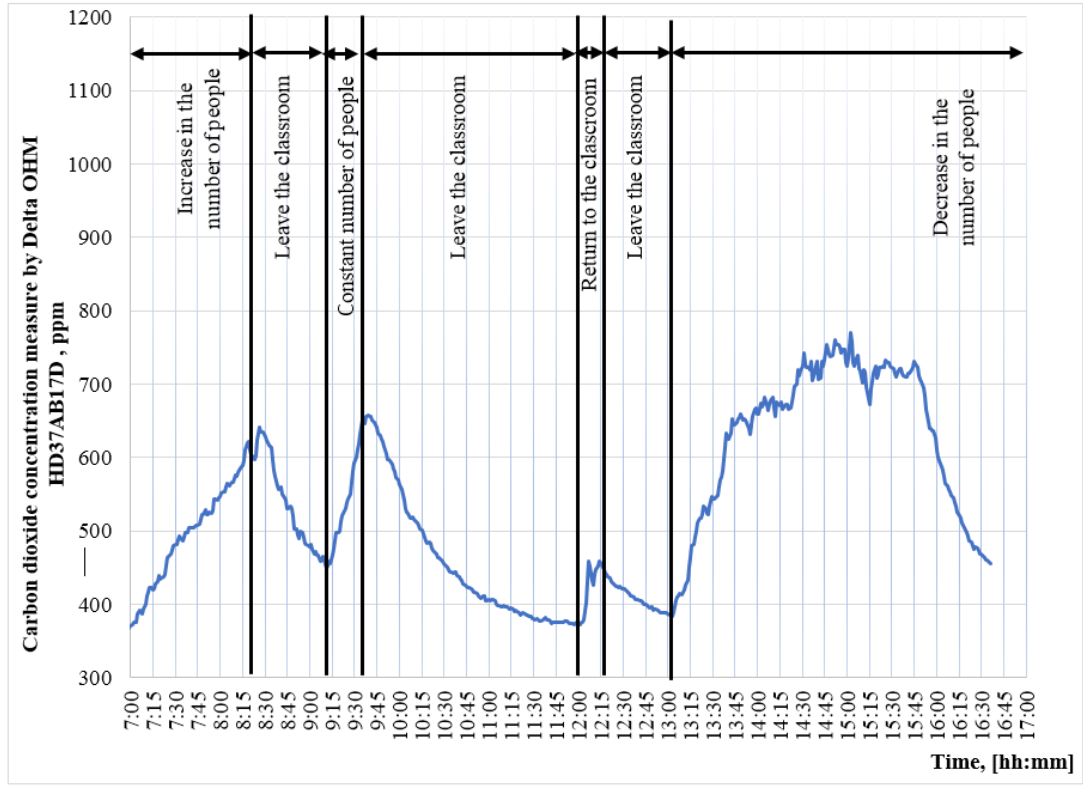

Fig. 2. Carbon dioxide concentration measurements- Day 2.

Figures 1 and 2 show that carbon dioxide concentration increases, when the children are most active, but never exceeds $1000 \mathrm{pm}$ - an indication that enough air is supplied to the room. As the number of occupants decreases, so does carbon dioxide concentration, as expected. Based on this, the first of the hypotheses was eliminated. 


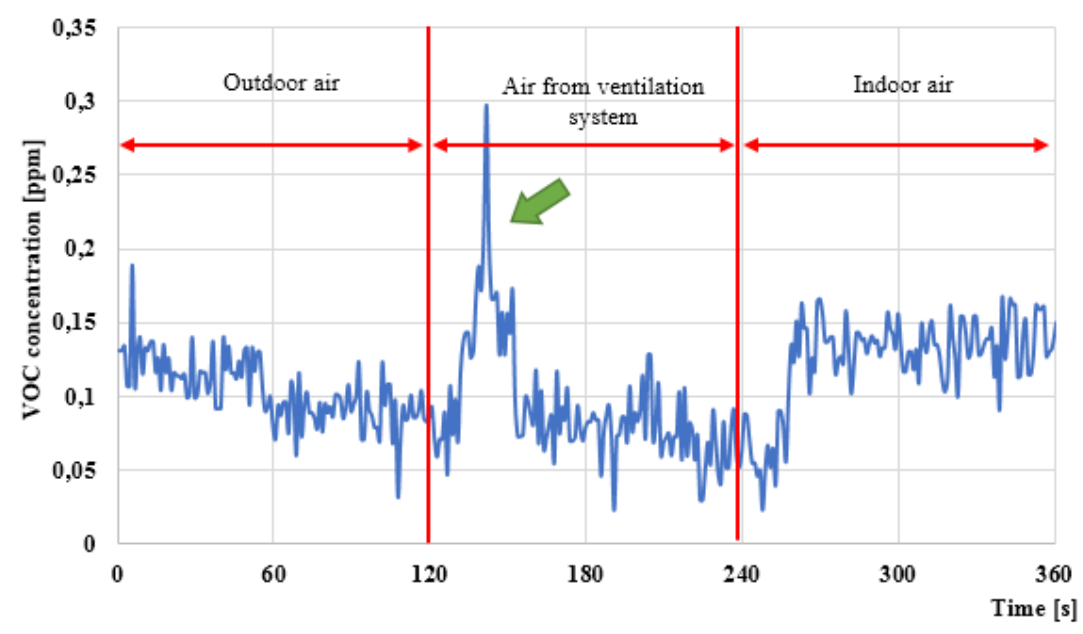

Fig. 3. VOC concentration measurements in the outdoor, indoor, and supply air in the classroom.

The measurements were done one after another, in order that is shown on the Fig.3, the duration of each one was two minutes. It was established that VOC levels in the outdoor and supply air are very similar, while indoors VOC levels are higher (Fig. 3). The peak in the supply air area was caused by the movement of the device (marked with an arrow on the Figure). Since contamination of the indoor air is higher than that of the outdoor air, it was established that the outdoor air is not the source of odors in the room.

Table 4. Air flow through exhaust valves.

\begin{tabular}{|c|c|}
\hline Air grilles symbol & Air flow \\
\hline- & $\mathrm{m}^{3} / \mathrm{h}$ \\
\hline $\mathrm{W} 3 / 3$ & 95 \\
\hline $\mathrm{W} 6 / 1$ & 33 \\
\hline $\mathrm{W} 6 / 3$ & 48 \\
\hline $\mathrm{W} 6 / 2$ & 57 \\
\hline $\mathrm{W} 3 / 4$ & 93 \\
\hline $\mathrm{W} 3 / 3$ & 55 \\
\hline $\mathrm{W} 3 / 1$ & 101 \\
\hline Total & 105 \\
\hline
\end{tabular}

Table 5. Air flow through supply valves at $48 \mathrm{~Hz}$ and at $60 \mathrm{~Hz}$.

\begin{tabular}{|c|c|c|}
\hline Diffusers symbol & Air flow, $48 \mathrm{~Hz}$ & Air flow, $60 \mathrm{~Hz}$ \\
\hline- & $\mathrm{m}^{3} / \mathrm{h}$ & $\mathrm{m}^{3} / \mathrm{h}$ \\
\hline $\mathrm{N} 1 / 8$ & 250 & 317 \\
\hline $\mathrm{N} 1 / 7$ & 141 & 205 \\
\hline Total & $\mathbf{3 9 1}$ & $\mathbf{5 2 2}$ \\
\hline
\end{tabular}

Tables 4 and 5 present the results of air flow measurements taken with a vane anemometer. W3/3, W6/1 etc. are symbol of grilles. N1/8, N1/7 are symbol of diffusers. That measurements shown disparity of the exhaust and the supply. The data shows that the exhaust air flow is $196.0 \mathrm{~m}^{3} / \mathrm{h}(50.0 \%)$ larger than the supply air flow at $48 \mathrm{~Hz}$ (the default frequency of the supply fan's power inverter). 
The imbalance lead to negative pressure in the room. Since a garbage chute is adjacent to the classroom, the contamination was most likely due to the infiltration of air from the chute. However, while inspecting the supply unit, the possibility of increasing the supply air flow (by increasing the frequency of the fan's power inverter from 48 to $60 \mathrm{~Hz}$ ) was affirmed. As Table 4 shows, changing the frequency of the inverter allowed for an increase of $131 \mathrm{~m}^{3} / \mathrm{h}$ of supply air flow. After the operation the supply air flow, at $522 \mathrm{~m}^{3} / \mathrm{h}$, constituted $88.9 \%$ of the exhaust air flow- substantially decreasing the negative pressure in the room and the intensity of contaminated air infiltration. Additionally, the employees were advised to keep the supply fan running at all times (it was being turned off when an unpleasant odor would appear).

The introduced measure resulted in the improvement of indoor air quality in the classroom- the employees no longer reported unpleasant odors.

\subsection{Classroom 2}

In classroom 2, $\mathrm{CO}_{2}$ concentration measurements were taken for three consecutive days. Additionally, design schematics were reviewed and the ventilation system itself was inspected. Based on the findings, following causes of inadequate air quality in the room were proposed:

- The boundary $\mathrm{CO}_{2}$ level at which air flow through the room is increased was set improperly,

- Placement of the $\mathrm{CO}_{2}$ sensor upsets readings,

- Incorrectly set timing program (weekly cycle) controlling the fan was in place.

- The supply air flow is insufficient.

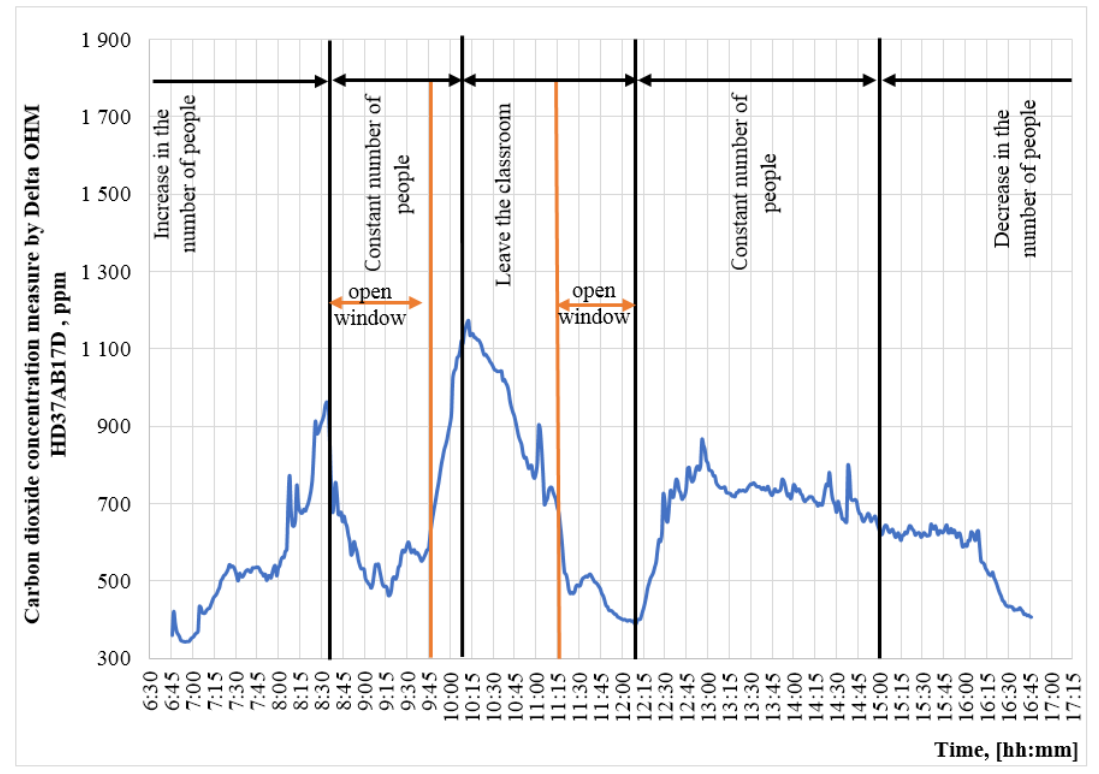

Fig. 4. Carbon dioxide concentration measurements- Day 1.

On the first day (Fig. 4), no apparent malfunction of the system was recorded. Until 12 am, $\mathrm{CO}_{2}$ concentration was fluctuating due to the various disturbances the system was subjected to: varying amount of people and the opening and closing of windows (while window valves remained closed). After the windows were closed and valves opened, 
carbon dioxide level was oscillating around $800 \mathrm{ppm}$, which would suggest the fan was operating correctly.

On the second day (Fig. 5) the adequate control of the inverter was recorded - as $\mathrm{CO}_{2}$ level exceeded the boundary of $1000 \mathrm{ppm}$ the fan velocity increased, reducing it. The visible peaks of concentration were caused by the students standing/ sitting directly by the sensor recess.

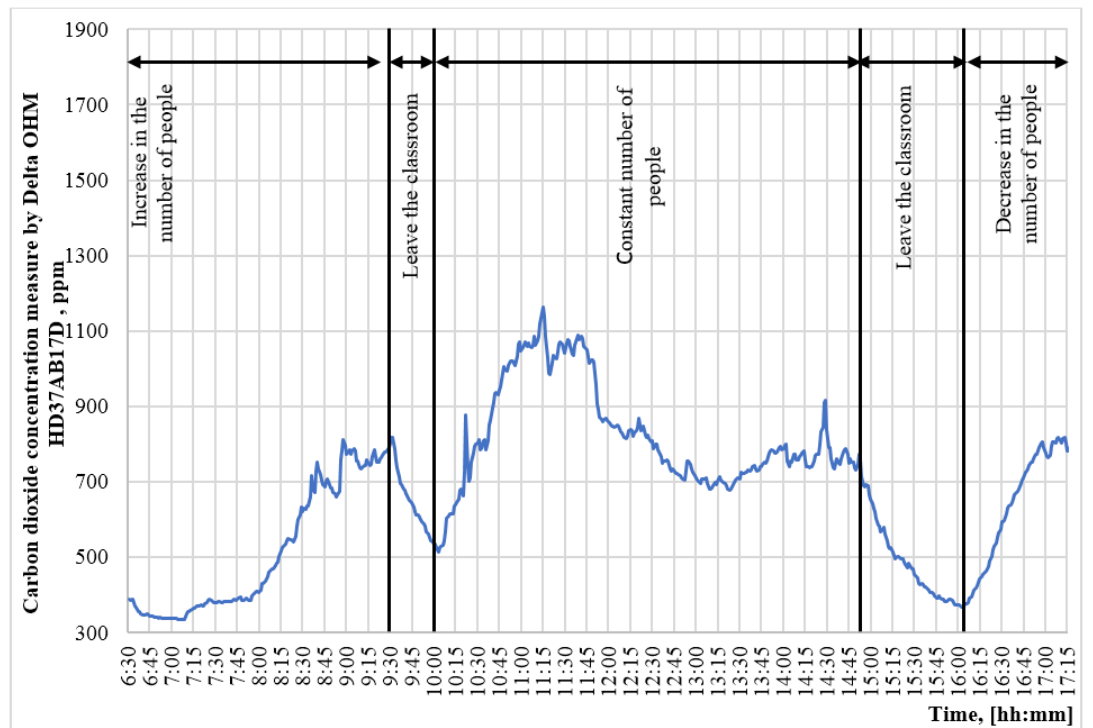

Fig. 5. Carbon dioxide concentration measurements- Day 2.

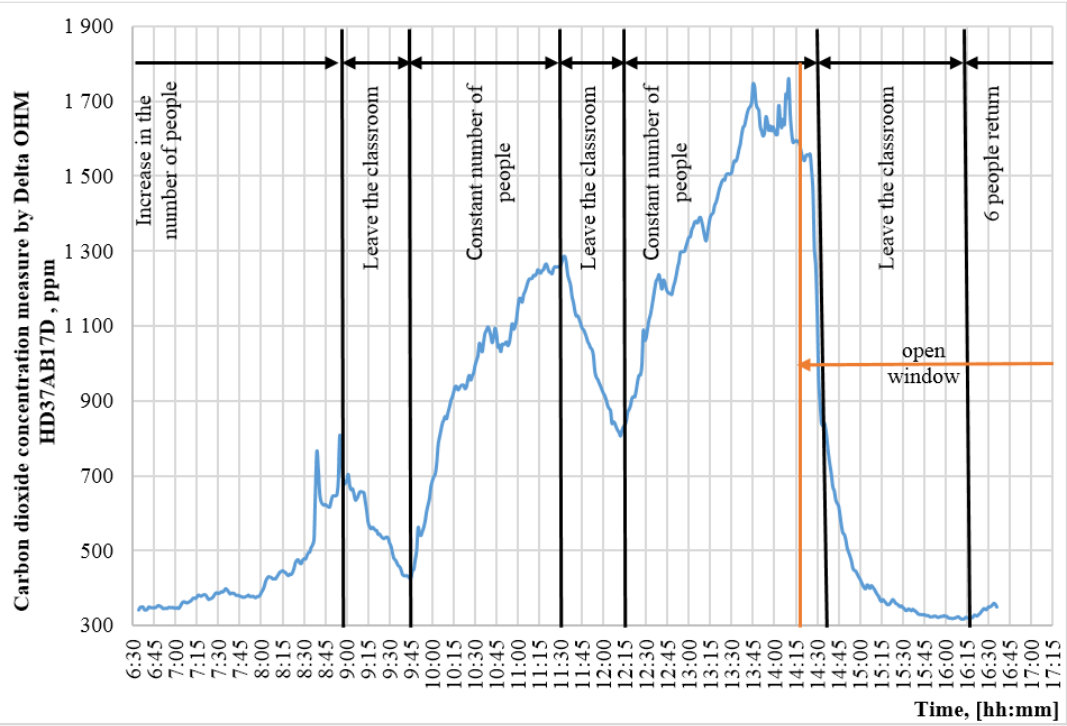

Fig. 6. Carbon dioxide concentration measurements- Day 3.

However, on the third day (Fig. 6) the fan only operated for 30 minutes between 7.00 and $8.00 \mathrm{am}$. During that day, the $\mathrm{CO}_{2}$ levels could only be controlled by opening the windows. The $\mathrm{CO}_{2}$ concentration was periodically higher than the ,comfortable" $1000 \mathrm{ppm}$. It is presumed the sudden change in the system adequacy was caused by faulty 
control parameters (timing program- weekly cycles). However, further investigation into the matter was limited at the time, due to the lacking in detail of the design documentation.

Based on taken measurements, it was established that the supply air flow in the classroom was sufficient. The update of the automation software and further measurements are advisable, since day-to-day measurements varied drastically. Currently the school is investigating the issue.

\section{Conclusions}

- Inadequate indoor air quality is a visible problem in classrooms and may cause the occupants to fall ill,

- Establishing the cause of improperly operating mechanical ventilation system is possible after reviewing design schematics and taking basic measurements,

- Mechanical ventilation system may not guarantee satisfying air quality when poorly designed or operated,

- Even though the buildings complied with the building code, indoor air quality standards were not met,

- Occupant access to system controls should be limited, as not to allow unqualified personnel to disturb the operation of the system

\section{References}

[1] Obwieszczenie Ministra Infrastruktury i Rozwoju z dnia 17 lipca 2015r. w sprawie ogłoszenie jednolitego tekstu rozporzadzenia Ministra Infrastruktury $w$ sprawie warunków technicznych jakim powinny odpowiadać budynki i ich usytuowanie (Dz. U. $\mathrm{Nr}$ 75. Poz. 1422), (2015)

[2] Wspólna publikacja Dyrekcji Generalnej Komisji Europejskiej ds. Zdrowia i Konsumentów i Wspólnego Centrum Badawczego, Sinphonie. (2014)

[3] R. Almeida, et al, EE, E 10(4), 839-854, (2017)

[4] U. Satish, et al., EHP, E 120, 1671-1677, (2012)

[5] B. Zabiegała, M. Partyka, J. Namieśnik, Nowe horyzonty $i$ wyzwania $w$ analityce $i$ monitoringu środowiskowym, (2003)

[6] World Health Organization, EURO Reports and Studies 78, WHO, (1983)

[7] J. Fedryn-Grygierek, Zeszyty naukowe Politechniki Śląskiej, E 1787, 57 - 70, (2008)

[8] J. Madureira, et al., Hum. Ecol. Risk Assess., E 15(1), 159-169, (2009)

[9] T. Salthammer, et al., Environ. Int., E 94, 196-210, (2016) 